\title{
OMANIZATION POLICIES AND ENTREPRENEURSHIP
}

\author{
Siham Said Sultan Al Hinai* \& Kausar Yasmeen $†$
}

\begin{abstract}
This study mainly focuses on influence of system and policies on businesses in Oman. The study explores the strength, weakness, opportunities and challenges of entrepreneurship initiatives. This project strategizes plan and solution thereof to improve Omanization program, entrepreneurship, local worker's commitment and skill. To achieve the objectives, qualitative method is used. In qualitative method, convenient sampling and semi-structured questionnaire were implemented to conduct interview and finally content analysis and thematic analysis was applied. The finding reveals that lack of related business experience, education, knowledge (formal and informal education and tacit knowledge), traditional thinking of bureaucrats in ministries, lengthy procedure to start business and omanization policies and business network are the key factors that hinder entrepreneurial initiatives. Wage policies and employee quota or ratio are also discouraging individuals to take entrepreneurial initiative. Entrepreneurial and business education is given in English medium instead Arabic that also cause of low level of understanding to theoretical knowledge of entrepreneurship in Oman. There is need to Replace Centralized system with Distributed System in Oman for businesses to increase entrepreneur businesses as because of lengthy procedure and centralize system many individuals give up to take initiate of business. Wages to labour should be paid on equilibrium level $(W L=S L=D L)$ for economic prosperity in the long run. Current study contributes socially, economically and politically.
\end{abstract}

Keywords: Wage Policies, Omanization, entrepreneurial initiatives, Qualitative research

\footnotetext{
CEMIS, University of Nizwa.

+ Department of Economics and Finance, University of Nizwa, Oman.
} 


\section{Introduction}

From the last 41 years, till now Omani economy is depending on oil, oil industry contributes 80 percent in government revenue. The government distributes the allowance to its citizen but still have 40 percent of the unemployment rate. According to forecasting by the central bank of Oman (2018) in Oman unemployment rate will hike up in future. On the other side, oil reserves are expected to finish after 20 years. So, it is important for Omanis to get involved in economic activities but the problem is, most of the Omanis prefer a high government post or high military rank to work that creates structural unemployment (Porter, 2004). It is not possible for the government to provide government jobs to all Omani, so Omani government have to find the alternative ways like entrepreneurship.

In most of the GCC countries, over $60 \%$ of the labour force are foreign (Ruppert, 1998). In Oman, 18.2 are Omani work force while 81.8 are NonOman. Over time many of the GCC countries become dependent on the cheaper and more qualified expatriate labour. In addition, expatriates generally work long hours, accept lower wages, tolerate poorer working conditions and physically demanding jobs which would not necessarily be accepted by the nationals (Al-Lamki, 1998; Eickelman, 1991; Shaeffer, 1989).

To decrease the unemployment and to be less dependent on foreigners, Omani government is permuting entrepreneurship and Omanization policy. On Omanization program the findings are mixed, some studies are in favour while some are not in favour of Omanization policy. Porter (2004) stated that the mobility and labour market is characterizing as rigid because of Omanization program. As Human Capital Challenge Report (2009) reported that 62 percent of Arab CEOs said that there is a lack of qualified national workers supply. Al-Busaidi (2000) reported that the national workers are less skilled and have less work commitment compare to foreign workers. More foreign worker's minimum wage isn't fixed, they are less expensive compared to Omani workers. On this point, it is important to discuss in the light of above-cited studies, that as every firm is profit seeker, they try to reduce the variable cost to maximize their profit, as per rationality, firms will provide the opportunity to less expensive and more skilled and Omani will remain unemployed, companies will give them jobs to fulfill the legal requirement. It is also important as Omani labour is perceived less committed and poor skill compare to foreign labour (Kuehn and Al-Busaidi, 2000), as per the rationality, again the probability of hiring to Omani will decline as every firm want to hire competent, highly skilled, committed and qualified workers so national individuals will get less chance to improve their skill to compete for the skilled labour market. So it is important to come out with the solution to improve the skill and commitment of national labour and solution to make the omanization policy successful. 
Al-Shanfari (2012) states that there is a need to identify, objectively, weak areas in the Omani macro environment that are hindering entrepreneurship development. Belwal, Balushi and Belwal (2015) found that majority of Omani reported in survey that they cannot do entrepreneurial activities because they have lack of knowledge, insufficient finance and macroeconomic variable hinder them to start their own businesses, So there is need to study the influence of macroeconomic variable on entrepreneurship and explore the other reasons that are faced by existing entrepreneur and hinder the initiate of entrepreneur in the emerging economy of Oman.

\section{Literature Review}

The developed countries are contributing ten times more to their GDP compare to Arab countries (World Bank, 2010; Ennis, C.A., \& WaltonRoberts, M. 2017). In the case of Oman, local contribute less to their GDP, more contribution comes from the oil industry. Because of oil, the government of Oman is able to contribute to their locals in the form of incentives but instead all of this, still have 40 percent unemployment rate (Steiner, 2018). As one percent increase in unemployment decreases the GDP by 2 percent (Patrick Gleeson, 2018). In Oman, entrepreneurship is facing many challenges and difficulties, that is treating economic development and growth' (Porter, 2003; Al-Lamki, 1998). For instance, in 2003, less than two in hundred new businesses were started, compared to one in ten in the United States (MOM, 2005). Omani prefers the government jobs; it's not possible to provide government jobs to all Omani (Atef, \& Al Balushi, 2017). To reduce the unemployment rate government is trying to permute entrepreneurship and omanization policy. Al Shezawi, Khan, \& Rahman, F. (2018) and Al-Shanfari, (2012) focusses on identifying problems that hinder interpretership for locals of Oman; the researcher mentioned that macroeconomic variables are expected to discourage the entrepreneurship in Oman. According toresearch, the weak and insufficient bureaucracy and the government was the cause of increasing $78 \%$ problems for doing business (Ennis, \& Walton-Roberts, 2017; Blanke et al., 2009). In the presentscenario, the Ministry of Social Development, Ministry of Commerce and Ministry of Manpower are playing their role in developing the small businesses, but their coordination system is reported poor that discourage doing business in Oman. Oman is exporting only 13.5 percent out of total export (MNE, 2009).

The Omanization program is introduced by the government of Oman, the purpose of this program is to adjust Omanilabour and decrease foreign labour in the public and private sectors, through the setting of nationalization objectives goals for each investment sector and government entity (Ali, et al, 2017). Porter, (2004) reported Omanization programme as rigid. In firing 
and hiring practices, latest Global Competitiveness Report 2009/10 ranked Oman is 89 out of 128 countries. They reported that omanization program is not cost effective and it is discouraging to those who want to enter in the market to start a new business, where the replacement of the less expensive and skilled international labour with sometimes less skilled national labour. 62 percent of Arab CEOs believe less supply of qualified local labour and fewer work moralities are seen in the locallabour force that was ranked on the third number; it is a most challenging issue for starting or doing business in Sultanate of Oman (Global Competitiveness Report, 2009; Al Wardi, 2016). Kuehn and Al-Busaidi (2000) conducted a comparative study of Omani workers and international workers and found that national works of Oman have less work commitment and work skill. The methodology part of Kuehn and Al-Busaidi (2000) has several foibles. However, there is need to cross check to check the validity and authenticity of findings. As the criteria for selecting participant need to improve, to conduct a study comparative study, the comparison should be made on the same level with same qualification, organization, environment etc.

Belwal, Al Balushi, \& Belwal, S. (2015) revealed that most of the postgraduate and undergraduate student wanted to start their own business, but they have lack of knowledge about starting a business and have fair of failure. So there is need to examine whether there is lack of knowledge that hinders the Omani to become a successful entrepreneur. Lack of financial assistance and technological innovation decrease the level of entrepreneurship. Oman is on 61 out of 128 countries in technological (Global Competitiveness Report, 2009). According to Porter (2004), doors for new business in Oman are closing owing to cultural factors. There is a shortage of self-made entrepreneur role models in the Omani (Buckingham, 2016; Moideenkutty, 2016).

Knowledge Gap: There is lack of studies that explore the strength, weakness, opportunities and challenges of the omanization program and entrepreneurship and strategize plan and solution thereof to improve omanization program, entrepreneurship, Omani worker's skill and commitment. The researcher could not find a single study that investigates the influence of omanization program on its GDP in the long run and short run. Many previous studies mentioned in literature conclude that omanization is rigid programme without discussing and considering the theories on economic fluctuation, these economic theories explain it's not necessary short run worse factor will also worse in the long run. The researcher could not find a comparative study that justify the sampling technique especially selection of specific participants to compare between local and foreign workers and robust the finding to check the reliability of the results. 


\section{Methodology}

The quantitative method will be applied to achieve the objectives. Through convenient sampling method jury and executive interviews were conducted. The participant was from Omani and Non-Omani head of enterprises, however those who have started new business (3- month) and those who wanted to start business (list of name and detail was taken from ministries) were considered. To collect the data regarding labour plisies interviews were conducted fromMinistry of Manpower. However, entrepreneurs from Muscat, Seeb, Ibri, Sohar, Slala was collected. The number of participants for interview was18, researcher stoped interviews when was getting repeated answer. This study usedsemi-structured interviews as it is a mix of unstructured and structured questions, some of the questions were written in advance, while others evolve during the interview. Thematic analysis and content analysis was used to answer the questions. Qualitative semi-structured interviews is one of the most dominant and widely used methods of data collection within the social sciences (Bradford \& Cullen, 2012).

\section{Results and Discussion}

\section{Exploring the strength, weakness, opportunities and challenges of omanization program and entrepreneurship initiatives.}

A number of constraints affect trade and investment in Oman. The country has a relatively small population and there is no high-value consumer market beyond the capital area. This situation is exacerbated by intense competition from nearby global trading hub Dubai and wellestablished industries in Saudi Arabia. In addition, other countries in the GCC typically offer higher industrial subsidies and lower quotas for hiring nationals. Omanization ratio is $90 \%$ in Banks, $60 \%$ in Establishment engaged in transport, stores and communication, $45 \%$ in Finance, insurance and real estate, $35 \%$ in Industry, 30\% in Hotels and restaurants, $20 \%$ in Wholesale and retail trade and $15 \%$ in Contracts according Government mandate on Omanization to be achieved by the end of 1996.Results have indicated that the Banking Industry is the only sectorial establishment that has almost achieved the targeted Omanization ratio of $90 \%$. Other establishments have been given a postponement to the end of the year 2000 (Omanization Follow-up Committee, 1999).

Destination Sustainability is a personalised consultancy and research firm in corporate sustainability and social responsibility. It brings together international best practices and global research and innovation with deep local expertise and regional cultural awareness in the field of corporate social responsibility, stakeholder and community engagement, sustainability systems and social impact measurement. 


\begin{tabular}{|c|c|}
\hline Omanization & Entrepreneurship initiatives \\
\hline $\begin{array}{l}\text { Strength } \\
\text { - Reducing unemployment on } 4^{\text {th }} \\
\text { level Staff. } \\
\text { - Loyalty of nationals } \\
\text { - Improved career opportunities, } \\
\text { including enhanced } \\
\text { opportunities to reach middle } \\
\text { and senior management } \\
\text { position in the industry } \\
\text { - Strengthened human resources } \\
\text { development culture } \\
\end{array}$ & $\begin{array}{l}\text { Strength } \\
\text { - Reducing unemployment } \\
\text { - Reducing dependency on government } \\
\text { - Less tax and inflation } \\
\text { - Infrastructure, advancement of the electricity } \\
\text { and energy sectors in the country are } \\
\text { available. Loan available. }\end{array}$ \\
\hline $\begin{array}{l}\text { Weakness } \\
\text { - Foreign worker's demotivation } \\
\text { - Lack of training to compete in } \\
\text { market } \\
\text { - Lack of training to improve } \\
\text { skill } \\
\text { - No motivation plan for Omanis } \\
\text { to increase their performance }\end{array}$ & $\begin{array}{l}\text { Weakness } \\
\text { - Omani have lack of information about the } \\
\text { procedures and other information about } \\
\text { inviting finance funds, commercial banks and } \\
\text { the bodies supporting entrepreneurs. } \\
\text { - Entrepreneur education is not really } \\
\text { producing entrepreneurs. } \\
\text { - Lack of training } \\
\text { - No motivation plan for Omanis to increase } \\
\text { their performance }\end{array}$ \\
\hline $\begin{array}{l}\text { Opportunities } \\
\text { - Slow learning } \\
\text { - Create jobs for Omani } \\
\text { - Training program for Omanis } \\
\text { - Business start-up because can } \\
\text { take loan }\end{array}$ & $\begin{array}{l}\text { Opportunities } \\
\text { - Oman has a strategic location outside the } \\
\text { Strait of Hormuz and is at the crossroads of } \\
\text { the Middle East, Africa, and Asia. Omani can } \\
\text { do trade on less cost (Geographic wise) } \\
\text { - In Oman neighbouring is china and India that } \\
\text { are considered big market, Omani business man } \\
\text { can get benefit from near located said countries. } \\
\text { - Oman offers political stability, physical } \\
\text { security, and a predictable investment } \\
\text { climate. Respect for free markets, property } \\
\text { rights, and rule of law is wide spread. } \\
\text { Residents have access to good health care } \\
\text { and schools, and easy logistical access to } \\
\text { global markets through a modern } \\
\text { infrastructure network. } \\
\text { - Entrepreneurs have the opportunity to meet } \\
\text { strategic partners and supporters of the } \\
\text { entrepreneurship and innovation environment } \\
\text { in the Sultanate. }\end{array}$ \\
\hline $\begin{array}{l}\text { Challenges } \\
\text { - Turnover of foreigners because } \\
\text { Omani have less skill } \\
\text { - Limited exposure of majority } \\
\text { of Omanis with global market } \\
\text { - Shortage of skilled labour }\end{array}$ & $\begin{array}{l}\text { Challenges } \\
\text { - Complicated and lengthy procedure to start } \\
\text { companies } \\
\text { - Quota system of employment/ratio } \\
\text { - Competition }\end{array}$ \\
\hline
\end{tabular}




\section{To identify the reasons of increasing the non-resident expatriate entrepreneurs more than Omani entrepreneurs.}

MoU aims at implementing a training programme for 20 social security students from grade 10 . The selection of students will be implemented in coordination with parents' councils. The programme aims at developing self-awareness skills, self-learning abilities, acquisition of research skills, among other skills and topics. Through Thematic analysis it is found that on individual level the Omani entrepreneur have lack of skill but not in all fields. Omani entrepreneur has lack of skill on both level (more educated Omani entrepreneur and less educated Omani entrepreneurs). The one of the reason education system connectivity with market. If the student study and practice business knowledge during his study duration, once he/she graduate will already business man. Later in market he will polish more to his skills but unfortunately Business students are getting more theoretical knowledge. That's why when they enter in market the fear of failure in business demotivate them and they afraid to take risk in businesses. The previous studies show risk taker win the markets. However, Omani majority is creative if they are given proper road map from study to market and from market to lead markets they can be successful businessman on global level. As geographic location and opportunities will help them to scale up their businesses.

Currently Omani have lack of commitment, experience awareness about procedure of businesses and how to do business because there is poor connectivity between theoretical and practical field. English language was also considered hurdle for Omani entrepreneurs when they deal with international businesses. Business correspondence Verbal and non-verbal among Omani was week. Non Omani supplier don't prefer to provide stuff to non-Omani entrepreneur or business as they trust more on non-Omanis. Indian supplier prefers to give their supply to Indian entrepreneur compare to Omani entrepreneur.

Hence, they have finance is also once cause because expect come with heavy investment and capture more shares in the market compare to Omanis. Business policies (for Omani policy should be different). Same business policies are applied on Omanis and non-Omanis that is somehow creating problems more than benefit.

Respondent "D" said:

"Expects working hours are more than Omani that's why expects are expected to increase firms profit by providing more output. More working hours are leading to expat to improve their learning day by day that not only polish their skill but leaving the Omanis behind in the market. Government is following up percentage of increasing omanization and Omani entrepreneurship involvement but there are not strong policies and plan to develop skill and will of Omanis" 
Respondent "C" said:

"We like to appoint former workers because they can work more hours compare Omani and are less expensive"

So minimum wage rule is Omani must be paid 325 Omani riyal on lower level jobs. The researcher concludes that this rule is partially good that can be explained as follows. Business man do businesses to increase profit, so if the Omani workers are given same salaries or less actually the chances of their hiring will increase. Companies will prefer Omani employee and will try to trained to make them more productive to increase their profit. This will lead them to improve their skill and will make them productive labor. However, on some posts their jobs should be only for Omanis like taxi drivers, security, on 4rth level while on medium and executive posts there should be ratio setting of Omanis and non-Omani. However, the replacing expects with Omani is good for Oman independency.

Main reasons of increasing the non-resident expatriate entrepreneurs

Lack of Micro Factors among Omanis

1.Skill and Will

2. Failure fear and motivation

3. Social commitments

4. experience

5. Awareness about procedure of businesses and how to do business

6. Risk taking

7. Connectivity between theoretical and practical field

8. Business correspondence Verbal and non-verbal

9. Credit (N-O don't prefer to give stuff to Omani on Credit compare to NO)
Lack of Macro Factors among Omanis

1. Gov Policies

2. Classical Thinker bureaucrats

2. Education

3. Counselling centre and Training in educational institute and for less educated businessman

4. Fund conditions 
There should be cross method of employment, expect should bound to appoint only Omani staff they should be given opportunity of appointing non Omanis only if with that specification of job Omani is not avail able under the special approval of government institute. For Omani local companies and businesses, there should be given choice to hire as per their convenience but training and expert expects consultant must be part of their companies. Lack of awareness to get debt funding available for new and growing firms, Lack of business culture and business competition among nationals were also find causes among Omani entrepreneur. Some Omani have finance to start business, they know what to do but they don't know, who, where and when to do businesses even they were not aware what is the procedure to start trade.

Mr. "B" said:

"I don't have money problem but I don't know how to do businesses, I don't know who can guide me I went Dubai but I couldn't find businesses exhibition or consulting center in Oman. Mostly we buy items from UAE while expat have network and mostly they find item on lower rate compare to us, when they go in market they can earn more profit on offering low price as I said if we buy expensive we can't offer same price so weak network and price discrimination leave us behind in earning profit relative to non-Omani entrepreneurs".

\section{To compare the skill and commitment of Omani labour to foreign labour.}

Porter (2004) stated that the mobility and labour market is characterizing as rigid because of Omanization program. As Human Capital Challenge Report (2009) reported that 62 percent of Arab CEOs said that there is a lack of qualified national workers supply. Al-Busaidi (2000) reported that the national workers are less skilled and have less work commitment compare to foreign workers.

Respondent "D" said:

"Expects working hours are more than Omani that's why expects are expected to increase firms profit by providing more output. More working hours are leading to expect to improve their learning day by day that not only polish expect their skill but leaving the Omanis behind in the market. Government is following up percentage of increasing omanization and Omani entrepreneurship involvement but there are not strong policies and plan to develop skill and will of Omanis".

However, base on the secondary information it is observed that in most of the research paper that compare the skill and commitment of Omanis don't provide justified sampling method. For example, first, Porter (2004) 
don't clearly write who were these CEOs, Omani or Non Omani. Based on what criteria the CEOs made this judgement or compared. Al-Busaidi (2000) reported that the national workers are less skilled but this author also don't provide a athentic and accepted criteria to of comparision. As to compare two groups, A group must have same characteristics, culture and environment, for exapme comparing exacutive post with clerk is not logical or if worker of Company working in multinational compacy in muscat and worker B worng in small business in Izki cant be compared because both have different knowledge and awearness etc.

However, the researcher found in banking sector, omanis are working their skill and commitment compare to non-omani working in other bank was not really different. Both have almost on equall level or somewhere omani were more productive because of arabic language correspondence.

\section{To find the results of Omanization programs on GDP in short run and long run.}

In Oman there is still need of non-Omanis in different fields. After content analysis this study conclude that Omanization policy is good for short run for economic prosperity of Oman because its providing employment to Omanis. However, in the long run many Omani policies can fire back. Only it's not important to provide jobs to Omanis it's also important to make Omani labour productive and skilled for long run economic prosperity of Oman.

\section{Recommendations, strategizing plan and solution thereof to improve Omanization program, entrepreneurship.}

First, There is need to Replace Centralized system with Distributed System in Oman to permute the businesses. Second, Labour should be treated as it is treated in free market. Wage of labour should be paid when supply for labour equal to demand for labour. Third, Government can remove the Law of minimum wage and can achieve its objective by fixing employment quota/ration of employment of Omani and non-Omani in companies. Fourth, The SANAD Program was developed to target Omani youth in particular by granting loans to those interested in pursuing selfemployment. any provision of finance must be accompanied by a comprehensive training program, mentoring scheme or ideally both. Fifth, The bureaucrats working in Oman mostly have classical thinking, they have experience but need to update their knowledge with today market. Educated and competent youth has knowledge, motivation of learning (that will make them expert) and have more stamina to work, Omani youth remain updated with today market, they should be given chance and preference to work in ministries on executive posts and especially in policy making. Every ministry should have research and problem solving centre related business, 
ministries need to update their policies through research and development centre recommendations.

Reverse Model of employment quota for long Run Oman economic Prosperity

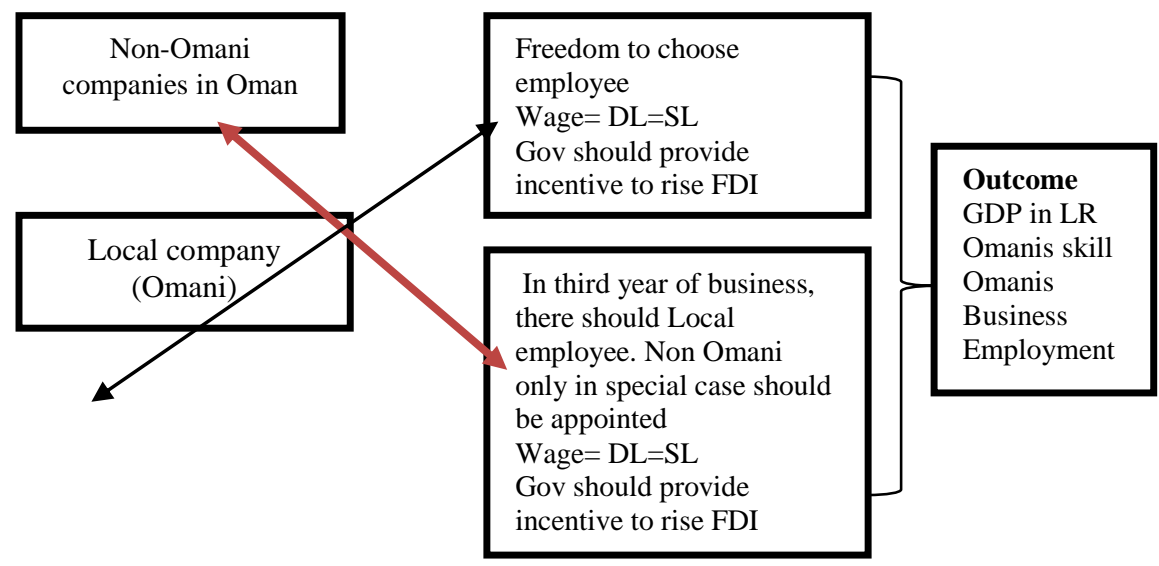

\section{Conclusion}

The main aim of this project is to explore the strength, weakness, opportunities and challenges of Omanization program and entrepreneurship initiatives. It also examines the influence of entrepreneurial education, and macroeconomic variables on entrepreneurship initiatives. Finally, this project strategizes plan and solution thereof to improve Omanization program, entrepreneurship, local worker's commitment and skill. To achieve the objective mix method is used. In qualitative analysis content analysis and thematic analysis was applied to achieve the objective while in quantitative the multinomial regression was used. Interviews in qualitative while cross sectional data by random sampling. The finding reveals that lack of experience, education, business network, lengthy procedure and Omanization itself are the key factors that effect on entrepreneurial initiatives. The companies should have the opportunities to register though ministries located in their cities. There is need to Replace Centralized system with Distributed System in Oman for businesses. Wages to labour should be paid on equilibrium ( $\mathrm{WL}=\mathrm{SL}=\mathrm{DL}$ ) for economic prosperity in the long run. Current study contribute socially, economically and politically. A significant majority (92\%) of the overall private sector employment are non-Omanies (expatriates). The predicament presents a major challenge to realisation of the government's goal of Omanizing the private sector. The SANAD Program was developed to target Omani youth in particular by granting 
loans to those interested in pursuing self-employment. While clearly a positive step in enabling the youth to pursue entrepreneurial endeavours, the authors would question how effective the initiative can actually be due to the fact that while funding is clearly an important ingredient to a successful start-up, it may well be negated by a lack of experience and expertise. It is the opinion of the authors that to be truly effective and efficient, any provision of finance must be accompanied by a comprehensive training program, mentoring scheme or ideally both. Education system must be link with industry and student should start involving in businesses during study.

\section{Bibliography}

Al Shezawi, H.A., Khan, D., \& Rahman, F. (2018). In-Country Value (ICV)-Entrepreneurial Opportunities in the Companies of Oman.

Al Wardi, Y.M., Jeevarathinam, S., \& Al Sabei, S.H. (2016). Eastern bodies in western cockpits: An anthropometric study in the Oman military aviation. Cogent Engineering, 3(1), 1269384.

Ali, Y.Y., Alani, F., Khan, F.R., Badi, A., \& Hamood, L. (2017). Employment in the Private Sector in Oman: Sector-Based Approach for Localization.

Al-Lamki, S.M. (1998). Barriers to Omanization in the private sector: The perceptions of Omani graduates. International Journal of Human Resource Management, 9(2), 377-400.

Al-Shanfari, D.A. (2012, January). Entrepreneurship in Oman: A snapshot of the main challenges. In Proceedings of the United Nations Conference on Trade and Development: Multi-year expert meeting on enterprise development policies and capacity-building in science, technology and innovation (STI).

Arab human capital challenge. (2009). Dubai, UAE: Mohammed Bin Rashid Al Maktoum Foundation in cooperation with Price Waterhouse Coppers.

Atef, T., \& Al Balushi, M. (2017). Omani tourism and hospitality students' employment intentions and job preferences: Ramifications on Omanization plans. Quality Assurance in Education, 25(4), 440-461.

Belwal, R., Al Balushi, H., \& Belwal, S. (2015). Students' perception of entrepreneurship and enterprise education in Oman. Education+ Training, 57(8/9), 924-947.

Blanke, J., Browne, C., Hanouz, M.D., Geiger, T., Mia, I., \& Sala-i-Martin, X. (2009). The global competitiveness report 2009-2010: World Economic Forum.

Buckingham, L., \& Ramachandran, K. (2016). Between the Covers: A Case Study of Scholarly Journal Publishing in Oman. Language, Identity and Education on the Arabian Peninsula: Bilingual Policies in a Multilingual Context, 166, 220. 
Ennis, C.A., \& Walton-Roberts, M. (2017). Labour market regulation as global social policy: The case of nursing labour markets in Oman. Global Social Policy, 1468018117737990.

Ennis, C.A., \& Walton-Roberts, M. (2017). Labour market regulation as global social policy: The case of nursing labour markets in Oman. Global Social Policy, 1468018117737990.

Gupta, S.K. (1989). Entrepreneurship development: The Indian case. Journal of Small Business Management, 27(1), 67.

Hedeker, D. (2003). A mixed-effects multinomial logistic regression model. Statistics in medicine, 22(9), 1433-1446.

Kuehn, K.W., \& Al-Busaidi, Y. (2000). A Difference of Perspective: An exploratory study of Omani and Expatriate Values and Attitudes. International Journal of Commerce \& Management, 10(1), 74-90.

McFadden, D., \& Train, K. (2000). Mixed MNL models for discrete response. Journal of applied Econometrics, 447-470.

Moideenkutty, U., Murthy, Y.S.R., \& Al-Lamky, A. (2016). Localization HRM practices and financial performance: evidence from the Sultanate of Oman. Review of International Business and Strategy, 26(3), 431442.

MOM. (2005). Third symposium on employing national manpower, Shinas, Oman. Ministry of Manpower.

Öztürk, E., Bolay, Ş., Hickel, R., \& Ilie, N. (2013). Shear bond strength of porcelain laminate veneers to enamel, dentine and enamel-dentine complex bonded with different adhesive luting systems. Journal of dentistry, 41(2), 97-105.

Porter, H. (2003, September). A Culture of Enterprise. Business Today, 51-52.

Porter, M. (2004). Competitiveness and Economic Development: Implications for Oman. Lecture presented at Sultan Qaboos University, Sultanate of Oman on 1 December 2004.

Reynolds, P.D., Bygrave, W.D., Autio, E., \& Arenius, P. (2004). GEM 2003 global report: Babson College. SQU. (2008). Scientific research abstracts Deanship for Postgraduate Studies and Research, Sultan Qaboos University: SQU Press.

Steiner, R.T. (2018). Between Oil Pasts and Utopian Dreams: Making State and Economy in Oman's Citizen Labor Industry.

Train, K., McFadden, D., \& Johnson, R. (2000). Discussion of Morey and Waldman's "Measurement error in recreation demand models". Journal of Environmental Economics and Management, 40(1), 76-81.

UNDP. (2004). Unleashing entrepreneurship: Making business work for the poor: Report to the Secretary-General of the United Nations by the Commission on the Private Sector \& Development. New York: UNDP. 1 March.

World Bank. (2010). Doing Business 2010. Washington, DC: The World Bank Group, IFC and Palgrave MacMillan. 